\title{
СИТУАЦІЙНІ ЗАДАЧІ У ВИКЛАДАННІ БІОЕТИКИ ЯК МІЖДИСЦИПЛІНАРНОЇ НАУКИ В МЕДИЧНІЙ ОСВІТІ
}

Т. І. Толокова

\author{
ДВНЗ “Тернопільський державний медичний університет \\ імені I. Я. Горбачевського МОЗ Украйни”
}

\section{SITUATIONAL TASKS IN TEACHING PROCESS OF BIOETHICS AS INTERDISCIPLINARY SCIENCE IN MEDICAL EDUCATION}

\author{
T. I. Tolokova \\ SHEI "Ternopil State Medical University by I. Ya. Horbachevsky of MPH of Ukraine"
}

\begin{abstract}
Важливим завданням кафедри медичної біоетики і деонтології є формування клінічного мислення, усвідомлення, що справжній прогрес без високої моралі, поваги до гідності людини - неможливий. Ситуаційні задачі використовуються для виявлення кінцевого рівня знань. Основний напрямок навчання студентів відповідає сучасним вимогам системи охорони здоров'я.
\end{abstract}

An important task of the department of medical bioethics and deontology is formation clinical thinking, awareness genuine progress without high morals, respect for human dignity - is impossible. Situational tasks are used to estimation of the final level of the students' knowledge. The main direction of the students' studying process satisfies modern requirements of the health care system.

Вступ. Головною метою медичної освіти є підготовка медиків, які, окрім успішного застосування спеціальних знань для лікування пацієнтів, зможуть надавати духовний, цілісний супровід хворим і шанувати життя від його зачаття аж до смерті. Під час навчання у вищих навчальних закладах необхідно розвинути у майбутніх лікарів уміння володіти основними принципами біоетики та деонтології при безпосередньому контакті з пацієнтами, членами їх сімей, опікунами, а також у колективі працівників у галузі охорони здоров'я [1].

Одним із шляхів досягнення цієї мети є оптимізація навчального процесу шляхом впровадження нових методів оволодіння матеріалом та контролю знань студентів.

Важливим завданням кафедри медичної біоетики i деонтології є уніфікація викладання питань, які на даний час включені до різних розділів навчальної програми, та допомога у систематизації сучасних поглядів на біоетичні проблеми у світовій спільноті, що вплине на формування клінічного мислення, пізнавальних здібностей майбутніх лікарів, спостережливості на основі здобутих у процесі медичної освіти спеціальних знань.

3 цією метою на заняттях передбачене вирішення ситуаційних задач та ділові ігри, які грунтуються на

(C) Т. І. Толокова клінічному досвіді американських і європейських фахівців і містять приклади їх вирішення, які показують шляхи виходу із проблемних ситуацій на засадах біоетики і етичних засад різних релігійних конфесій.

Основна частина. Систематичне дослідження моральних параметрів, включаючи моральну оцінку, рішення, поведінку, орієнтири інших наук про життя i медичне лікування, із залученням різноманітних етичних методологій до міжпредметного формулювання [2] відбувається на кафедрі медичної біоетики і деонтології.

Коло проблем, що вимагають розгляду з позицій біоетики, включає зокрема біоетику допоміжних репродуктивних технологій і профілактики вроджених вад розвитку; біоетичні аспекти клінічних випробувань, реєстрації нових лікарських засобів і медичних технологій; етичні аспекти клінічної практики; експерименти на тваринах і альтернативні методи досліджень у біології й медицині; екологічну етику і безпеку сільськогосподарської продукції. Пренатальне обстеження ембріона, штучне запліднення, сурогатне материнство - це звичні медичні практики у світовій медицині [3].

Досвід розв'язування ситуаційних задач у подальшому позитивно вплине на вміння об'єктивізувати спеціальні медичні знання, на формування логічного мислення та лікарської інтуїції [4]. 
Студенти повинні усвідомити, що справжній прогрес у галузі охорони здоров'я без високої моралі, поваги до гідності людини - неможливий.

Ситуаційні задачі з біоетичною проблематикою $\epsilon$ надзвичайно збалансованою структурою для формування комунікативних навичок, уяви, вміння логічно прогнозувати розвиток поведінкових реакцій. Вони допомагають оцінити отримані в ході вивчення теоретичного матеріалу знання, вдосконалити систему контролю знань, навичок і вмінь майбутнього лікаря.

Клінічні ситуації дозволяють використовувати набуті теоретичні знання про дотримання біоетичних принципів у законодавчому полі вітчизняного та міжнародного медичного права в цілому в розв'язанні реальних проблем різних практичних випадків у повсякденній практиці працівника галузі охорони здоров'я.

Задачі є різні за тематикою біоетичних питань.

Студентам пропонується вихідний рівень інформації, який містить короткі дані анамнезу клінічного випадку звернення за медичною допомогою, особливості учасників ситуації, дані щодо медичної допомоги та спілкування з питань іï̈ надання.

Згідно з вимогами навчальної програми, ситуаційні задачі формуються відповідно до тем, які запропоновані до практичного заняття, враховуючи базовий рівень знань студентів-першокурсників.

Умови задачі завдання ставлять лаконічно і чітко. Мета цієї частини контролю знань - допомогти майбутньому лікарю краще зрозуміти тему, її ключові моменти, додатково опрацювати фундаментальну літературу з дисципліни.

Так, наприклад, задачі для перевірки знань правових й біоетичних основ законодавства про трансплантацію органів і тканин людини містять інформацію про реципієнта, який потрапив у лист очікування пересадки органа та етичну дилему, що виникла у зв'язку з підбором донора, а студент повинен пояснити медичні й етичні критерії справедливого розподілу донорських органів: гістосумісність, невідкладність, черговість.

Інші задачі покликані перевірити вміння студента визначити оптимальний порядок спілкування з пацієнтами, членами їх родини та медичними працівниками, задіяними в лікувальному процесі, в контексті дотримання принципу конфіденційності та поінформованої згоди, організувати правильну послідовність обміну інформацією між учасниками лікувального процесу.

У групах студентів з викладанням основ біоетики i біобезпеки англійською мовою використовуються завдання для тестового контролю і ситуаційні задачі для перевірки знань, отриманих під час самостійної, позааудиторної підготовки та навчальних карт до практичної частини заняття. Крім того, студенти отримують індивідуальне самостійне завдання для детальної підготовки однієї з тем біоетичної проблематики, в складі якої студенти самостійно складають ситуаційну задачу.

На практичному занятті розгляд теми починається з короткого фронтального експрес-контролю базових знань студентів. Для перевірки знань студентів викладач використовує тестові питання багатоваріантного вибору і ситуаційні задачі, в яких необхідно зазначити біоетичні принципи, що лежать в основі аргументації дій лікаря. Контроль якості відповіді студента здійснюється за допомогою еталонів відповідей.

Етапний контроль засвоєння студентами матеріалу виконується за допомогою системи навчання, в якій застосовано пошук шляхів розв' язування різноманітних ситуацій, пов'язаних з низкою біоетичних проблем у діяльності практикуючого лікаря, акцентування уваги студентів на опрацюванні теоретичного матеріалу (навчальних карт, відеоматеріалів) та застосуванні отриманих знань у різних клінічних випадках, баченні ними нових проблем у відомих стандартних умовах, усвідомленні функцій медичних працівників різних рівнів відповідальності, в умінні визначити можливі, в тому числі нетипові шляхи вирішення проблем.

У ході заняття використовуються моменти ділової гри, де один зі студентів у певній клінічній ситуації виконує роль медичного працівника на певних етапах надання медичної допомоги, а іншому студенту відводиться роль пацієнта, або інших осіб, які беруть участь у лікувальному процесі (середній і молодший медичний персонал, члени сім'ї пацієнтів, медичні представники фірм-виробників виробів медичного призначення, науковці). У розгляді такої клінічної ситуації висловити свою думку мають можливість всі учасники дискусії, що допомагає розглянути існуючі ліберальні й консервативні позиції щодо вирішення біоетичних дилем у галузі біомедицини.

Розширені завдання 3 детальним викладанням основ біоетики і біобезпеки та оволодінням прийомами виділення головної думки тексту, порівняння відеоматеріалу, який наводиться на практичній частині згідно з тематикою заняття, пропонуються у другій половині семінарської частини для закріплення здобутих комунікативних навичок та застосування теоретичних знань і розв' язанні конкретних практичних завдань. 
У рамках самостійної позааудиторної роботи студентів ситуаційні задачі розміщені у методичних рекомендаціях для позааудиторної роботи. Це допомагає у мотивації особистої активності студентів, комунікативних навичок, підготовки базового рівня знань для розвитку та формування клінічного мислення, а варіанти правильних відповідей дозволяють перевірити дії у різноманітних щодо біоетичної поведінки ситуаціях.

Проблематика всіх практичних занять у курсі “Основи біоетики і біобезпеки” взаємопов' язана оволодінням та вмінням аналізувати основні принципи біоетики. Кінцевий рівень знань студентів оцінюється за допомогою розв'язування задач, у яких описано умови, обставини, учасників певного випадку у клінічній практиці та сформульована низка питань стосовно біоетичної проблематики. При вирішенні задач студент

\section{Списоклітератури}

1. Основи біоетики і біобезпеки. Програма навчальної дисципліни для студентів вищих медичних навчальних закладів III-IV рівнів акредитації.-К., 2011.

2. Stephen G. Post Encyclopedia of Bioethics / Post Stephen Garrard. -3rd ed. p. cm. New York : Gale Group, Inc., a division of Thomson Learning, Inc., 2004. - 3062 p. повинен вміти оцінити варіанти належного вирішення проблеми залежно від обставин, вказаних в умові, а також дати інтерпретацію тих чи інших вчинків учасників подій залежно від причин виникнення певної дилеми у поведінці медичного працівника.

Висновки: 1. Тематика ситуаційних задач з дисципліни “Основи біоетики і біобезпеки" випливає 3 положень типової програми з навчальної дисципліни, сприяє закріпленню знань, отриманих під час опрацювання навчальних карт та відеоматеріалів.

2. Результати оцінювання знань студентів за допомогою тестових ситуаційних задач з багатоваріантним вибором відповідей висвітлюють грунтовність знань студентів і $€$ складовою оцінювання.

3. Ситуаційні задачі допомагають у контролі теоретичних знань та пов'язують отримані навики 3 майбутньою професійною діяльністю в медицині.

3. Запорожан В. М. Біоетика : підручник / В. М. Запорожан, М. Л. Аряєв. -К. : Здоров'я, 2015. -288 с.

4. Мисула І. Р. Оптимізація навчально-виховного процесу в Тернопільській медичній академії в умовах сьогодення / І. Р. Мисула // Медична освіта. - 1999. - № 1. - С. 44-48.

Отримано 05.02.15 